\title{
Welfare Professions in Transition
}

\author{
I Annette Kamp
}

\author{
DOI \\ 10.19154/njwls.v6il.4882
}

elfare professions constitute one of the backbones in the development of the

Nordic welfare states. Working in the public sector was for decades associated with high status; public sector employees were trusted employees. Through their work, they had important responsibilities for the welfare state and its citizens. To provide job security - through employment as officials—was a part of ensuring the stability of the state (Åkerstrøm, 2001), and we saw the establishment of what could be called a public ethos, a special morality aimed at serving the needs of the citizens and the state (Hoggett, 2005).

The term welfare professions is widely used, referring to public sector employees in the field of, for example, health, education, care, and social work. So this term covers professionals who work directly in contact with patients, citizens, clients, students, etc. (Brante, 1990; Järvinen \& Mik-Meyer, 2012). Along with the development and modernization of the welfare state, a number of new welfare professions, such as pedagogues, social works, physiotherapists, social care assistants, and auxiliary nurses have joined the existing ones like nurses, teachers, psychologists, and physicians.

At the same time, however, the public sector has undergone dramatic changes as part of a neoliberal transformation of the welfare state. With the New Public Management (NPM) wave from 1980s and onwards efforts to restructure public institutions and introduce market-like relationships between them, to outsource and privatize public services and to transform citizens to customers in a market have prevailed (Busch, 2005; Christensen \& Lægreid, 2007; Greve, 2008). Within this reform strategy, welfare professionals are perceived as part of the problem that NPM is created to solve, namely an uncontrollable and wildly growing bureaucracy (Clarke \& Newman, 1997).

So, the Nordic variant of NPM is in fact paradoxical. On the one hand, professionalism and development of new welfare professions has been a key element. On the other hand, NPM implies attempts to challenge the professions' monopoly to assess the quality of work by installing rational and standardized management models. While new professionalism is cultivated, its autonomy is defied (Dahl \& Rasmussen, 2012). Some authors propose that the increased focus on efficiency, monitoring, and accountability may give rise to a new form of "NPM-professionalism," where professional work is turned into service products, clients into customers, and the professionals are encouraged to be "enterprising change agents" (e.g., Evetts, 2009). On this background, tensions and contradictions in the working life of welfare professionals, or even more profound changes in profession identity and ethos should be expected.

However, it is important to observe that changes may be much more complex. Along with NPM, the public sector has been hit by a true reform wave. In many respects, NPM 
still seems to be going strong, having a large impact on the work and professional identity of the employees within the welfare sector. Simultaneously, however, other developments occur. For example restructuring, quality reforms, LEAN, etc., are interacting with and perhaps in some cases counteracting the principles of NPM. Part of the picture of the changing Nordic welfare sectors in the last decade is large-scale reforms induced by politicians attempting to integrate different types of welfare work and facilitate crossfunctional cooperation. Further, focus on technological innovations in service provisions is increasing. Moreover, since the financial crisis the consistent focus on reducing and savings in the public sector is an important feature (e.g., Christensen \& Læareid, 2011).

Altogether, this variety of more or less independent traits of development creates an impression of an increasingly complex context for work that the employees have to deal with, combine, or prioritize between, as part of their daily working life. This being said, the specific field, for example, health, education, or social work, and the local context, are of great importance (Bovbjerg, 2012). Which specific reform elements are being brought into the field and how they are negotiated locally may vary significantly, so studies that are sensitive toward the specific contextual conditions are of great value.

There is a strong and longevity tradition for Nordic research within this area. I will however not provide an extensive review of this comprehensive body of research in this place, but only shortly sketch up different paths this research has taken. This thematic issue is the second issue of Nordic Journal of Working Life Studies that focusses on working life in the public sector, and may be seen as a continuation. For a broader discussion and review of this literature, you may consult the introduction to our previous thematic issue (Kamp et al., 2013).

The research on consequences for welfare professions of this development takes different departures. Part of it focus on dilemmas and strains introduced by the clash of rationalities-contradictions between, for example, economic rationality and care rationality-experienced by welfare professionals, or on the strategies developed by the professionals to develop a meaningful work and to make ends meet (see, e.g., Wærness, 1984; Vabø, 2007; Dybbroe, 2008; Baadsgaard, 2012). Other parts highlight how welfare professions' ethos, identity, and work are transformed by different forms of standardization that may cause fragmentation of work, but may also define and redefine the professional universe and its key concepts (see, e.g., Kamp, 2012; Tufte, 2013; Ahrenkiel et al., 2013). Transition in professional identities is also in focus when studying implications of changes of relation between professionals and clients. As explained above, NPM implies attempts to position the citizen as a costumer that actively choose between services at a market, thereby creating new positions for both professionals and clients. But also concepts like "citizen-centered service" have a great impact, particularly in the Nordic social and health sector. Here, citizens are given greater responsibility for their own recovery, while professionals' role is to guide or educate them (Kjær \& Reff Pedersen, 2010; Hansen, 2015). It has to be mentioned that gender perspectives play a crucial role in this research tradition and greatly contribute to explaining dynamics in the development of welfare professions, and point out consequences in terms of (lack of) recognition of certain parts of work (e.g., Christensen, 2004; Dahl, 2009).

Finally, while managers can hardly be counted as welfare professionals, NPM has nevertheless implied an increasing focus on governance, and accordingly to the development of new groups of managers who are requested to take on an identity as professional

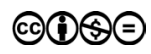


managers, thus replacing their welfare professional identity with a leader identity. The consequences for social relations, for professional identity, and the contradictions that may be inherent in these positions are important new research areas (see, e.g., Hansen \&Voxted, 2012; Rasmussen, 2012).

\section{Contributions}

This thematic issue was initiated by a successful and well-visited workshop on Professional work in the Nordic welfare states at the Nordic Working Life Conference in summer 2014, reflecting a long-standing interest for working life in the public sector among Nordic Working Life researchers.

It consists of seven articles, which all deepen our understanding of how welfare professions and their work are changing. They concern different parts of the public sector: elderly care, health care, psychiatry, daycare, and job centers. Two of them address the identity and strains of public managers.

The first two articles both study the subjective accounts of professionals in elderly care, probably the sector that has been most intensively subjected to NPM-inspired reforms and lately also to retrenchments.

In the first article, "Material constructions of care workers identity," Sanne Laulainen and Anneli Hujala explore the relation between materiality-such as smells, physical space, cleanness-and identity. Taking departure in social constructionism, they address the taken-for granted effects of materiality on identity and focus particularly on how the physical environment influences identity constructions among care professionals in Finnish nursing homes. On the basis of accounts gathered through nonactive role-playing, they point out how good physical environments conditions were described almost as dreamlike. Exploring the strategies developed in order to maintain status and positive identity, they show how ignoring or downplaying were common, while rebellion seldom occurred. They point out how these strategies reflect the conflicts between the physical conditions and the maintenance of positive professional identities, and argue that this problem needs to achieve greater attention, both among professionals and managers.

In the next article, "What is a good working place? Tracing the logics of NPM among managers and professionals in Swedish elderly care," Britt-Inger Keisu, Ann Öhmann, and Birgit Engen show how neoliberal ideals of organizational effectiveness and good working life are widely present in interviews with managers and professionals within this sector. On the basis of qualitative interviews, they show how four archetypical storylines are represented. Three of them are very much in line with current neoliberal discourses on the good and effective workplace, leadership, and management, namely the effective mission-oriented bureaucrat, the passionate employees, and the inter-professional teamwork. The fourth represents a conflictual perspective, maintaining a critique of structural conditions and focus on traditional labor relation. However, managers and professionals draw on different discourses. While managers construct their identity embracing NPM, professional's constructions are more ambiguous, as they both embrace ideals of interprofessional teamwork and resist changes drawing on the critical approach.

Standardization in the health sector and the impact on professional identities and practices is the main focus of the two following articles. The articles highlight how different forms of standardization in quite different parts of the health sector may change, 
what is considered as professional work, thereby challenging professional identities and inter-professional collaboration.

In "Evidence based Nursing in the EID: from caring to curing," Jette Ernst address the turn toward evidence-based practices within medicine that have resulted in massive standardization, and point out how this development resonates very well with a development within nursing toward further scientification, and thus to a greater focus on curing as opposed to the traditional focus on caring. In her extensive field work at a Danish Integrated Emergency department, she identifies several ways of addressing evidence-based medicine. Some eagerly embrace the curing approach and view it as creating new career pathways. Others see it as a threat and attempt to undermine the core of their nursing skills. However, as the author points out, the largest group of nurses simply juggle to make the standards work, acknowledging that standardized solutions often come short of answers and are unable to guide actions. So, Ernst argues that evidence-based medicine may lead to transformation of professional identities, but in fact, professional clinical knowledge is necessary to guide practice and ensure good patient care in situations that are often unpredictable.

In "Struggles of professionalism and emotional labour in standardized mental health care," Annette Kamp and Betina Dybbroe demonstrate the highly skilled emotional labor carried out in mental health care. On the basis of ethnographic field studies in a Danish child psychiatric unit, they show how different forms of standardization, resulting from quality reforms, Lean and NPM, upset the balance between humanistic and medical aspects of psychiatry, and challenge professional identities, interdisciplinary collaboration, and hierarchical relations. The ramifications of this development are many. The authors point out how this development in fact increases emotional labor, as a result of strained relations to both colleagues and clients, while at the same time emotional labor is made still more invisible, as it is excluded from the standardized schemes that define what counts as work. Moreover, they show that the professionals try to negotiate paradoxes in order to make ends meet.

The next article "Autonomy and emotion management - middle managers in welfare professions during radical change," also address the emotional side of work, but with a focus on middle managers in Norwegian child welfare service. Hulda Njöll Gunnarsdottir study how middle managers in Norwegian child service respond to constraints in autonomy during radical change. Middle managers are not only executing and managing change but are also submitted to change themselves. They are under pressure, as they are supposed to be loyal to both their superiors and their employees. Gunnarsdottir shows through a qualitative study, comprising both interviews and document analysis, how middle managers try to manage and contain the emotions of their employees, as well as their own emotional dissonance. She explores the strategies that middle managers employ in order to maintain their sense of autonomy, and outline a number of factors that are conditional for managers' emotional management.

Managerial work is also the focus for the next article: "Letting go of management? Struggles over managerial roles in collaborative governance." Here, Mie Plotnikof explores how New Public Governance, which is considered a post-NPM paradigm but work alongside NPM, creates new roles for managers. New Public Governance implies an emphasis on collaboration across sectors, partnership, networking, and lateral modes of organizing, implying that new ideals on managerial roles are developed. On the basis of a ethnographic study of managers in Danish daycare, Plotnikof show how managers

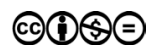


negotiate their positions in what turns out to be conflictual and highly complex situations. Becoming a facilitator of the very diverse set of stakeholders is not a unproblematic process for the managers, and Plotnikof demonstrate how managers are not just involved in changing their role, the process is actually better understood as an endeavor to position between multiple roles continuously.

In the last article: "Getting sick and disabled people off temporary benefit receipt: strategies and dilemmas in the welfare states frontline," Heidi Moen Gjersøe points out how welfare professionals through their daily practices manage to maintain some of the welfare state responsibilities, in spite of reforms that to a large extent aim to dismantle them. She investigates the strategies applied by the front-line officers within the Norwegian Labour and Welfare Service, when they manage the difficult task of assessing the work capabilityof the long-term sick and disabled. Paradoxically, their practice leads to locking the clients with complex problems in receipt of temporary benefits, thus not leading to neither work nor permanent disability benefits. Gjersøe points to the officers' lack of discretion as an important factor explaining this dynamic. On the basis of field studies and interviews with officers at two frontline offices, she demonstrates how frontline officers navigate in a complex situation with a lack of control, guided by an aim secure the clients a safe and secure income as well as a smooth workflow.

\section{References}

Ahrenkiel, A. Nielsen, B.S., Schmidt, C. Sommer, F. and N. Warring (2013). Unnoticed professional competence in day care work. Nordic Journal of Working Life Studies 3, (2), 79-95.

Andersen, N.Å. (2001). Karlighed og omstilling, København, Nyt fra Samfundsvidenskaberne.

Baadsgaard, K., Jørgensen, H., Nørup, I. \& Olesen, S. P. (2012) Fra klientorienteret arbejde til administrativt arbejde-ændringer i den faglige praksis og kvalificering på det beskæftigelsespolitiske område. Tidsskrift for Arbejdsliv, 4, 30-47.

Bovbjerg, K.M. (red.) (2011). Motivation og Mismod. Effektivisering og stress på danske offentlige arbejdspladser, Aarhus, Aarhus Universitetsforlag.

Brante, T (1990). Professional types as a strategy of analysis. In: Burrage, M., Torstendahl, R. (eds.). Professions in Theory and History - rethinking the Theory of Professions. London, Sage Publications. pp. 75-93.

Busch, T., Johnsen, E., Klausen, K. K. \& Vanebo, J. O. (2005) Modernisering av offentlig sektor. Utfordringer, metoder og dilemmaer. Oslo: Universitetsforlaget.

Christensen, K. (2004) Silent voices—on gender-related power in public care services. In: Waerness, K. (ed.) Dialogue on Care. Bergen: University of Bergen. Centre for Women's and Gender Research. pp. 119-145.

Christensen, T. \& Lægreid, P. (2007) Introduction-theoretical approach and research questions. In: Transcending New Public Management-The Transformation of Public Sector Reforms. Aldershot: Ashgate. pp. 1-16.

Christensen, T. \& Lægreid, P. (2011) Complexity and hybrid public administration-theoretical and empirical challenges. Public Organization Review, 11, 407-423. doi: http://dx.doi.org/10.1007/s11115-010-0141-4.

Clarke, J. \& Newman, J. (1997) The Managerial State. London: Sage.

Dahl, H. M. (2005) A changing ideal of care in Denmark: a different form of retrenchment? In: Dahl and Eriksen (eds.) Dilemmas of Care in the Nordic Welfare State, Continuity and Change. Aldershot: Ashgate. pp. 47-61.

Dahl, H. M. (2009) New public management, care and struggles about recognition. Critical Social Policy, 29(4): 634-654. doi: http://dx.doi.org/10.1177/0261018309341903. 
Dahl, H. M. \& Rasmussen, B. (2012) Paradoxes in elderly care. The Nordic model. In: Kamp, A. \& Hvid H. (eds.) Elderly Care in Transition: Management, Meaning and Identity in Work-A Scandinavian Perspective. Copenhagen: Copenhagen Business School Press. pp. 29-49.

Dybbroe, B. (2008) Crisis of care in a learning perspective. In: Sirpa Wrede et al. (eds.) Care Work in Crisis-Reclaiming the Nordic Ethos of Care. Lund: Studentlitteratur. pp. 41-48.

Evetts. J. (2009). New professionalism and new public management. Changes. Continuities and consequences. Comparative Sociology, 8, 247-266. doi: http://dx.doi. org/10.1163/156913309X421655.

Greve, C. (2008) Contracting for Public Services. London: Routledge.

Hansen, A.H. (2015). Rehabilitating elderly bodies and selves. New forms of care work, professional identity and status in rehabilitative home care. $\mathrm{PhD}$ thesis. Roskilde University

Hansen, K. R. \& Voxsted, S. (2012) Ledere i første række. Tidsskrift for Arbejdsliv, 4, 68-83.

Hjort, K. (2001), Moderniseringen af den offentlige sektor. Frederiksberg, Samfundslitteratur.

Hoggett, P. (2005). A service to the public: The containment of ethical and moral conflicts by public bureaucracies. In: du Gay, P. (ed.). The Values of Bureaucracy, Oxford, Oxford University Press. Pp 165-190.

Hood, C. (1991). A public management for all seasons, Public Administration, 69 (1), 3-19. doi: http://dx.doi.org/10.1111/j.1467-9299.1991.tb00779.x.

Järvinen, M. \& Mik-Meyer, N. (2012). At skabe en professionel. København, Hans Reitzels Forlag.

Kamp A. (2012). Meaning of work in Danish elderly care. Fragile reconstructions. In: Kamp A., \& Hvid H. (eds.). Elderly Care in Transition. Management, Meaning and Identity at Work. København, Copenhagen Business School Press.

Kamp, A., Kjemsdal, L \& L. Gonäs (2013). Working in the public sector. Introduction to thematic issue. Nordic Jornal of Working Life Studies, 3(2), 1-8.

Kjær, P. \& Reff-Pedersen, A. (eds.) (2010) Ledelse gennem patienten. Nye styringsformer $i$ sundhedsvosenet. København: Handelshøjskolens forlag.

Klausen, K. K. m.fl. (2005). Modernisering av offentlig sektor. Utfordringer, metoder, dilemmaer, Oslo, Universitetsforlaget.

Rasmussen, B. (2004) Between endless needs and limited resources. Gender, Work \& Organization, 5(11), 506-526. doi: http://dx.doi.org/10.1111/j.1468-0432.2004.00245.x.

Rasmussen, B. (2012) New public management. Constructing a new management identity in care for the elderly. In: Kamp, A. \& Hvid, H. (eds.) Elderly Care in Transition: Management, Meaning and Identity in Work-A Scandinavian Perspective. Copenhagen: Copenhagen Business School Press. pp. 165-187.

Tufte, P. (2013). Is there time enough? Nordic Journal of Working Life Studies, 3(2), 97-112.

Vabø, M. (2007) Organisering for velferd. Hjemmetjenesten i en styringsideologisk Brytningstid. Bergen: NOVA Rapport 22/2007.

Wærness, K. (1984) Rationality of caring. Economic and Industrial Democracy, 5, 185-211. doi: http://dx.doi.org/10.1177/0143831X8452003. 